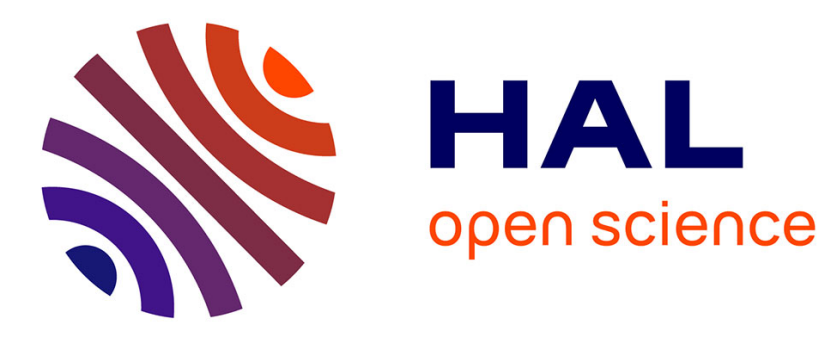

\title{
MINERALS AND THE EMERGENCE OF LIFE
}

Simon Duval, Kilian Zuchan, Frauke Baymann, Barbara Schoepp-Cothenet, Elbert Branscomb, Michael J. Russell, Wolfgang Nitschke

\section{To cite this version:}

Simon Duval, Kilian Zuchan, Frauke Baymann, Barbara Schoepp-Cothenet, Elbert Branscomb, et al.. MINERALS AND THE EMERGENCE OF LIFE. Metals, Microbes, and Minerals - The Biogeochemical Side of Life, De Gruyter, pp.135-158, 2021, 10.1515/9783110589771-011 hal-03163239

\section{HAL Id: hal-03163239 \\ https://hal.science/hal-03163239}

Submitted on 9 Mar 2021

HAL is a multi-disciplinary open access archive for the deposit and dissemination of scientific research documents, whether they are published or not. The documents may come from teaching and research institutions in France or abroad, or from public or private research centers.
L'archive ouverte pluridisciplinaire HAL, est destinée au dépôt et à la diffusion de documents scientifiques de niveau recherche, publiés ou non, émanant des établissements d'enseignement et de recherche français ou étrangers, des laboratoires publics ou privés. 


\title{
Minerals and the Emergence of Life
}

\author{
Simon Duval ${ }^{1}$, Kilian Zuchan ${ }^{1}$,Frauke Baymann ${ }^{1}$, Barbara Schoepp-Cothenet ${ }^{1}$, \\ Elbert Branscomb ${ }^{2}$, Michael J. Russell ${ }^{3,4}$ and Wolfgang Nitschke ${ }^{1}$
}
${ }^{1}$ Aix Marseille Univ, CNRS, BIP (UMR 7281), 31 chemin Joseph-Aiguier, 13402 Marseille Cedex 09, France <sduval@imm.cnrs.fr><kzuchan@imm.cnrs.fr><baymann@imm.cnrs.fr> <schoepp@imm.cnrs.fr><nitschke@imm.cnrs.fr>
${ }^{2}$ Carl R. Woese Institute for Genomic Biology, and Department of Physics, University of Illinois, Urbana, IL 61801, USA <brnscmb@illinois.edu> ${ }^{3}$ NASA Astrobiology Institute, Ames Research Center, California, USA
${ }^{4}$ Dipartimento di Chimica, Università degli Studi di Torino, via P. Giuria 7, 10125 Turin, Italy <michaeljrussell80@gmail.com>

\section{ABSTRACT}

1. BACK TO THE (THERMODYNAMIC) ROOTS OF LIFE

1.1. The Textbook Narrative: Life from Organic Molecules

1.2. The Organic Soup's Primordial Problem with Thermodynamics

1.3. Life Serves to Dissipate Environmental Disequilibria

2. THE TOP-DOWN APPROACH: WHAT CAN WE LEARN FROM EXTANT LIFE?

2.1. $\quad$ Life Is Fueled by Electrochemical Disequilibria

2.2. Bioenergetic Enzymes: A Functional Inorganic Heart Cladded in an Organic Shell

3. STRUCTURAL AFFINITIES BETWEEN CATALYTIC CENTERS IN METALLOENZYMES AND SPECIFIC MINERALS

4. MINERAL-CATALYZED REACTIONS PERTINENT TO EMERGENCE OF LIFE SCENARIOS 
5. CATALYSIS AND DISEQUILIBRIUM CONVERTERS, METALS AND

QUINONES/FLAVINS: AN ATTEMPT AT DISENTANGLING THE KNOT

6. ADDITIONAL LEVELS OF COMPLEXITY: LAYERED (CLAY-LIKE) MINERALS

6.1. Fougerite and Green Rusts

6.1.1. Softness of Internal Structure

6.1.2. Redox Softness, Electron Transfer, and Proton-Coupled Redox Transitions

6.1.3. Multi-Electron Redox Catalysis

6.2. A Potential Bridge from the Inorganic World to Biology

\section{CONCLUSION}

\section{ACKNOWLEDGMENTS}

\section{ABBREVIATIONS AND DEFINITIONS}

\section{REFERENCES}

Abstract: Metal-bearing minerals are an integral part of almost all "metabolism-first"-type scenarios for the emergence of life which consider that life is better defined by what it does than what it is made from. Since metals are formidable catalysts, these scenarios stipulate that early metabolic reactions (and prominently the reduction of $\mathrm{CO}_{2}$ to yield biomass) were performed by (mainly transition) metals contained in certain minerals. Metabolism-first scenarios stand in opposition to primordial soup hypotheses which envisage prebiotic synthesis of organic molecules as building blocks for life to be the salient feature enabling life to come into being. A critical analysis of the historical roots of these emergence of life hypotheses highlights fundamental inconsistencies prompting us to appeal to basic thermodynamic principles to provide rigorous guidelines for developing contradiction-free models. Combining these guidelines with our present-day understanding of biological energy conversion, arguably the process most fundamental to all life, strongly suggests an expansion of previous mineral-based scenarios to include processes converting environmental redox tensions into phosphate-grouptransfer disequilibria, i.e., the quintessential free energy converting mechanism of extant life. Based on their reported physicochemical and electrochemical properties, iron- (together with other transition metal-) based layered double oxyhydroxide (Fe-LDH) minerals such as fougerite 
are promising candidates to afford the required capacities and therefore may render previous mineral-based scenarios compliant with thermodynamic strictures.

Keywords: abiogenesis $\cdot$ alkaline hydrothermal vent $\cdot$ bioenergetics $\cdot$ disequilibrium converters - emergence of life $\cdot$ fougerite $\cdot$ green rust $\cdot$ greigite $\cdot$ mackinawite $\cdot$ transition metal clusters

\section{BACK TO THE (THERMODYNAMIC) ROOTS OF LIFE}

A contribution discussing a link between minerals and the emergence of life is, in the context of the prevalent scientific mindset, necessarily bound to raise eyebrows. Can there be anything more antithetical than organisms and rocks? And aren't organisms evidently, as already in their name, made up from organic matter, that is, hydrocarbons? Does that not imply that the reasons for why there is life must be within the realm of organic chemistry while of course minerals are the epitomes of inorganic chemistry? The combination of bottom-up considerations (that is, thermodynamic requirements) and of top-down evidences (i.e., fundamental characteristics of biological energy conversion, also known as bioenergetics) have convinced us of the necessity to question the very foundations of an origin of life contingent on organic molecules and to rather adhere to the thermodynamic view. In this view, life emerged from environmental disequilibria in the form of processes carried out by transition metal-containing minerals, driven by the tendency to efficiently dissipate these disequilibria. In the following we will elaborate on our reasons to adopt this stance.

\subsection{The Textbook Narrative: Life from Organic Molecules}

The notion that life originated from a "primordial soup" of organic molecules is presently almost unconditionally embraced, from popular culture to the dedicated research communities. Space exploration outreach, for example, strongly capitalizes on the promise of finding the "organic building blocks" in extraterrestrial environments. These building blocks are considered to 
eventually have found their way to planet Earth where they engendered life. It all seems to make sense - but does it really or have we just grown accustomed to a narrative which in fact, as we will argue, from a thermodynamic perspective doesn't make sense? To understand the philosophical roots of the organic soup hypothesis, we need to go back 200 years to when Western thinking went through a conceptual upheaval with respect to its vision of life and nonlife and to what distinguishes one from the other. Prior to Pasteur, abiogenesis and spontaneous generation, that is, the emergence of living things from abiotic matter, was nothing outrageous and taken to explain a plethora of empirical observations such as for example the emergence of fleas from dust [1]. In 1859 Pasteur did away with the concept of spontaneous generation [2] but thereby spontaneously generated a disturbing conundrum: what then is it that fundamentally distinguishes life from non-life? A plausible answer to this question was eventually afforded by the chemists who found that living organisms were mainly made up from hydrocarbons (proteins, lipids, sugars, etc.) which they accordingly called organic molecules yielding the nascence of the field of organic chemistry. It then was sensible and straightforward to posit that these organic molecules must somehow possess the ability to bring forward life, i.e., a "vital force". Vitalism was born and the majority of chemists and biologists, among them Louis Pasteur himself, adhered to this hypothesis as the most satisfactory way to make sense of all empirical evidences.

The advent of an atomistic understanding of chemistry at the beginning of the 20th century, however, dealt the death-blow to vitalism since there was nothing special to organic molecules as compared to their inorganic counterparts, apart from their higher structural complexity (a disputable claim in the light of some of the minerals we will discuss below) and no natural border between inorganic and organic chemistry could be defined. It is ironic that the detection of organic molecules in numerous extraterrestrial settings from the surface of Titan [3] through comet atmospheres [4] to interstellar space [5] is still systematically interpreted as evidence that the seed for life on Earth may have come from outer space rather than as showing that there is nothing special to complex hydrocarbons and that their synthesis is just chemistry.

The notion that organic molecules are the defining characteristics of life and hence its prerequisites thus has somehow survived the demise of vitalism and it is this failure to 
acknowledge that there is nothing "life-specific" to hydrocarbons which rendered the persistence of organic soup scenarios to the present day possible. Such scenarios, however, face extraordinary hurdles when assessed within the framework of the physical sciences.

\subsection{The Organic Soup's Primordial Problem with Thermodynamics}

As pointed out by Erwin Schrödinger [6] already in 1944, and even earlier by Ludwig Boltzmann as well as numerous further physicists and physical chemists ever since [7-11], all living entities share the same characteristics. They generate order, that is, highly structured and regulated networks of processes, from disorder, i.e., relatively randomly distributed chemical elements (Figure 1). Therefore, they are entropy-decreasing phenomena. The second law of thermodynamics of course tells us that spontaneous lowering of entropy in closed (that is, fully isolated from their environment) systems is unlikely and that this unlikelihood steeply increases with the number of elements making up the system. This means that the probability of generating even extremely rudimentary cellular entities from organic soup settings is virtually zero (Figure 1) and this probability further decreases with each and every complexification of such rudimentary cells. Since we definitively know that there is life on our planet, its origin was, in the framework of organic soup hypotheses, infinitely unlikely but obviously still has happened. This would imply that the origin of life on Earth was a one-off event and there basically would be no chance to find life elsewhere in the universe.

\section{insert Figure 1 in color close to here (landscape)}

Fortunately, we don't have to worry about all this since life is everything but a closed system! All living organisms depend on a continuous flux of free energy from their environment and therefore fully obey the requirements of the second law of thermodynamics. As already pointed out by Schrödinger, life must be a subsystem of a larger one which itself needs to be far from thermodynamic equilibrium. Life can exist because it accelerates the increase in entropy of the larger system, that is, takes it faster to its equilibrium state. The second law permits life to lower its own entropy (or, in other words, to generate order) if the increase of entropy of the larger system surpasses the entropy decrease within the subsystem Life. 


\subsection{Life Serves to Dissipate Environmental Disequilibria}

Not only does the free energy flux from the environment into cellular organisms render life compatible with the second law of thermodynamics, it even provides a rationale why life did emerge in the first place. Science has recognized and characterized a plethora of phenomena which basically do what life does, i.e., generate transient low entropy entities which serve to increase the entropy of a larger system they are part of. Frequently cited examples are atmospheric phenomena such as tornados, convective structures ("Benard cells") or spatial and temporal structure formation in chemical reactions (such as the iconic Belousov-Zhapotinsky reaction). These entities are called dissipative structures [7] and are shown by far-fromequilibrium thermodynamics to spontaneously and necessarily emerge under appropriate conditions (for more details see [8]). From the thermodynamic point of view, life must be such a dissipative structure or it simply could not be. The true requirement permitting, but also driving, life to emerge therefore lies in the existence of environmental disequilibria and of the mechanisms converting these disequilibria into the ordered metabolism of cellular entities rather than the mere presence of organic molecules in a primordial soup.

However, would it not be possible to reconcile thermodynamics and primordial soup hypotheses by assuming that both, environmental disequilibria and organic molecules, were indispensable ingredients to life's emergence and that life wouldn't have appeared unless both were present at the same time?

The fact that life overwhelmingly consists of organic molecules at first glance seems to bolster this view. However, the detailed ways of functioning in biological energy conversion unraveled over the last few decades attribute the role of essential agents to low-abundancy entities, that is, metals (mainly transition metals) and clusters thereof, rather than to the bulk organic substance of cellular life. In doing so, they provide a rationale for the empirical observation microbiologists had made very early on: no "trace-elements", no growth! In the following we will have a closer look at what bioenergetics in extant life actually is about and how it works. 


\section{THE TOP-DOWN APPROACH: WHAT CAN WE LEARN FROM EXTANT LIFE?}

\subsection{Life Is Fueled by Electrochemical Disequilibria}

The first major lesson to be gleaned from the diversity, but even more so from the underlying unicity of life's bioenergetic processes is that their free energy converting mechanisms universally exploit electrical tensions. While prokaryotes can indeed make a living from a bewildering variety of environmental sources of free energy, the molecular mechanisms they employ to this end are astonishingly homogeneous and the unifying aspect of all these free energy sources is that they ultimately are electrochemical [12]. Such environmental (or, for the case of photosynthesis, light-induced) electrochemical disequilibria are alleviated via electron transfers from reducing towards oxidizing redox substrates (Figure 1). These electron transfer events are mediated by bioenergetic chains which serve as converters of redox free energy into extremely out-of-equilibrium ATP/ADP ratios driving the ensemble of endergonic chemical reactions which characterize life by their inherent decrease in entropy. The coupling between collapsing redox tensions and build-up of ATP/ADP disequilibria is generally mediated by a transmembrane proton (and occasionally sodium) gradient (Figure 1) which is generated by the electron transfer chains and which drives in return the phosphorylating systems, in most cases ATP synthases or $\mathrm{H}^{+}$-translocating pyrophosphatases. High pyrophosphate $\left(\mathrm{PP}_{\mathrm{i}}\right)$ to orthophosphate $\left(\mathrm{P}_{\mathrm{i}}\right)$ levels can indeed play similar roles in certain prokaryotes as high ATP/ADP ratios do. All this can thus be likened to life being driven by an environmental battery [12] as depicted in Figure 1.

Biological energy conversion being fundamentally based on redox tensions raises the question of what is so special about electrochemical disequilibria. Part of the answer to this question may come down to the metastability of redox disequilibria where one-electron compounds need to react with strongly cooperative two-electron ones. A significant portion of environmental redox substrates in fact show strong redox cooperativity, such as the $\mathrm{H}_{2} / \mathrm{H}^{+}$, $\mathrm{CO}_{2} /$ formate, $\mathrm{NO}_{3}^{-} / \mathrm{NO}_{2}^{-}$, arsenate/arsenite couples, to name only the most common ones. 
Such two-electron compounds react only extremely slowly with one-electron redox centers as a result of their highly destabilized semi-reduced form (for a discussion of this phenomenon see [13]). Extant life by the way heavily relies on this electrochemical principle which allows the extremely cooperative two-electron compound $\mathrm{NAD}(\mathrm{P}) \mathrm{H}$ (with a stability constant for the halfreduced form of $K_{\mathrm{S}}=10^{-20}$ [14]) to float freely in the cytoplasm without becoming unproductively, chaotically and rapidly oxidized by the plethora of one-electron centers (mostly iron sulfur centers) present within cytoplasmic enzymes. The very long persistence compared to biological timescales, of the above mentioned environmental electrochemical disequilibria leaves sufficient leeway for the enzymes constituting bioenergetic chains (and others) to mediate reactions between two- and one-electron compounds and to couple these reaction schemes to the generation of ion-motive membrane potentials. Of course, fully-fledged bioenergetic enzymes certainly were not available at the time of life's emergence. However, their redox active cores were! As we will argue in the following section, these active centers are mainly made up from metals.

\subsection{Bioenergetic Enzymes: A Functional Inorganic Heart Cladded in an Organic Shell}

The very first 3D structures of a few bioenergetic enzymes were resolved about 30 years ago but it took about 20 more years until eventually all key enzymes of eukaryotic, that is, mitochondrial and plastidic bioenergetic chains were known to atomic resolution. In the realm of the much more diverse bioenergetics of prokaryotes, only a fraction of all known bioenergetic enzymes have their 3D structures resolved so far. However, we had quite detailed pictures of the structural make-up of the catalytic centers in these bioenergetic complexes well before their atomic coordinates were determined by X-ray diffraction and cryo-electron-microscopy. These pictures were afforded by spectroscopic methods such as EPR, EXAFS, XANES, Mössbauer, and the likes, many of which specifically detect metals and metal ions. Quite detailed geometries of the catalytically active metal centers and clusters thereof (mostly composed of particularly redoxversatile transition metals) had thus been deduced long before the molecular architectures of the protein scaffolds holding these active centers became resolved. The emerging picture is that of 
inorganic metal centers performing the energy-converting processes and redox reactions with their protein environments mainly adjusting and optimizing the metal clusters' properties. Without pretending to be exhaustive, we have presented several of the metal-centers playing essential roles in bioenergetic processes in Figure 2. While in many biochemistry textbooks enzymes are considered to be polypeptide chains which occasionally may recruit metals to improve catalysis, to the spectroscopists studying bioenergetic enzymes it was always clear that the crucial action happened on the metal clusters and not on the polypeptide (with admittedly a few amino acids assisting metal-catalyzed redox processes such as, for example, in cytochrome oxidase and photosystem II).

insert Figure 2 in color close to here (place legend on the opposite page)

Biological energy conversion, by thermodynamic standards the most fundamental process of life, in extant life employs also a few organic molecules such as quinones, flavins, and nicotinamides but remains first and foremost the business of a plethora of specialized inorganic entities, the diverse metal clusters. All this suggests that absolute abundance likely is a misleading criterion when looking for what is essential to life. As a provocative analogy, the high abundance of plastics in a computer should obviously not be taken as proof that it is these polymers rather than the semiconducting material which performs logical operations on binary states, i.e., the processes defining the apparatus.

\section{STRUCTURAL AFFINITIES BETWEEN CATALYTIC CENTERS IN METALLOENZYMES AND SPECIFIC MINERALS}

Despite all this, dedicated advocates of organic soup scenarios might well admit that the relevant processes are carried out by metal clusters but argue that it is the polypeptide chain that imposes their specific structural layout. This does not seem to be the case for the majority of studied metal clusters in metalloenzymes. As pointed out for example by Helmut Beinert $[15,16]$, many iron-sulfur clusters observed in enzymes also exist as inorganic entities in appropriate solvents. Inorganic models mimicking the geometries (and properties) of metal centers, metal clusters, and mixed-metal clusters in many metalloproteins have been synthesized and characterized. Even 
more tellingly from an evolutionary point of view, several biological clusters involved in pivotal types of free energy conversion have been observed to structurally resemble units making up the crystal lattices of certain minerals [17-21]. For these cases, life appears to merely have extracted these units from the bulk mineral by wrapping them in polypeptide chains $[22,23]$. The most iconic mineral:biocluster similarities (see Figure 3) have been reviewed in the past and we refer the reader to the relevant literature $[19,21]$. The main minerals suggested to be parent to intriguing metal clusters in biology are greigite, mackinawite, and fougerite, all of which are extremely likely or certain to have been present in specific locations on the Hadean and early Archaean planet Earth, that is, when life is supposed to have emerged. In particular, these minerals were probably constituents of the chimneys formed at submarine alkaline hydrothermal vents, which in addition also feature electrochemical and $\mathrm{pH}$ gradients providing the sine-quanon thermodynamic sources of free energy to drive life into being (cf. Section 1) and which have therefore been put forward as potential hatcheries of life [24-26]. The first mineral to be put forward as instrumental in an inorganic, metabolism-based emergence of life certainly was pyrite [27]. Pyrite has indeed been shown to perform a range of catalytic reactions potentially pertinent to emergence of life scenarios. However, a close inspection of pyrite's crystal lattice does not immediately suggest structural similarities to metal centers in biological systems.

insert Figure 3 in color close to here (width: $12 \mathrm{~cm}$ )

\section{MINERAL-CATALYZED REACTIONS PERTINENT TO EMERGENCE OF LIFE SCENARIOS}

Minerals, and in particular transition metal-containing ones, are renowned for their extraordinarily versatile catalytic abilities. However, only part of the manifold chemical reactions mediated by minerals is of obvious relevance to the problem of life's emergence. We have collected a subset of reactions which appear most noteworthy to us in the context of the emergence of life scenarios dealt with in this contribution (Table 1).

insert Table 1 close to here 


\section{CATALYSIS AND DISEQUILIBRIUM CONVERTERS, METALS, AND QUINONES/FLAVINS: AN ATTEMPT AT DISENTANGLING THE KNOT}

It appears important to us to emphasize the fundamental difference between catalysis and disequilibrium conversion. The very definition of catalysis implies that the catalyzed reaction is exergonic and thus would proceed even in the absence of the catalysts, only much more slowly. For example, the oxidation of molecular hydrogen by the nickel-iron ([NiFe]) cluster of certain hydrogenases in the presence of sufficiently oxidizing electron acceptors therefore represents straightforward catalysis. Members of so-called Group 4 [NiFe]-hydrogenases, by contrast, couple the redox interconversion of $\mathrm{H}_{2} / 2 \mathrm{H}^{+}$to translocation of a cation over the cytoplasmic membrane [41] and therefore perform genuine disequilibrium conversion. Several key disequilibrium conversions in bioenergetics, however, require the crucial participation of aromatic organic molecules, quinones and flavins. Both these aromats play crucial roles in the generation of out-of-equilibrium reductants via the process of electron bifurcation, the quinones mainly within the membrane-integral Rieske/cyt $b$ complexes and flavins in a wide variety of soluble bioenergetic enzymes [13,42-45]. Do these implications of quinones and flavins in disequilibrium-converting processes contradict the notion of primeval roles of metals in the emergence of life and instead bring the organics back to the forefront? Maybe but not necessarily. It has in fact been shown that molybdenum-based centers can in principle perform the cooperative two-electron reactions which are crucial to the mentioned roles played by quinones and flavins [46] and it has been argued that molybdenum (and/or tungsten) may have performed these reactions in nascent life $[13,44]$. The environmental scarcity of Mo and W may then early on have forced life to devise (organic) alternatives to these metals resulting in quinones and flavins taking over the respective tasks.

Alternatively, these aromats may have been produced as side products in disequilibriumconverting processes performed by a specific mineral (see $[47,48]$ and Section 6$)$ and thus may have been woven into the fabric of early metabolic reactions almost from the beginning. In any case, we would like to emphasize that, if quinones and flavins did indeed play pivotal roles 
already at life's onset, these roles would be dramatically different from those of organic building blocks envisaged by primordial soup scenarios. They rather would be dynamic actors in the prime processes of life's emergence: the conversion of electrochemical tensions into membrane potentials and onwards into high ATP/ADP ratios and the provision of out-of-equilibrium reductants (required for example for efficient $\mathrm{CO}_{2}$ reduction).

\section{ADDITIONAL LEVELS OF COMPLEXITY: LAYERED (CLAY-LIKE) MINERALS}

In Figure 3 and Section 4 we have discussed a few examples of minerals structurally resembling specific active clusters in metalloproteins as well as bio-relevant processes they have been shown to carry out. The cases of greigite, mackinawite and also pyrite have been discussed in the framework of metabolism-first scenarios for life's emergence since several decades [25, 49]. Relevant reactions in these minerals are basically surface chemistry since greigite, mackinawite, and pyrite are solids. The mineral fougerite, however, belongs to an entirely different structural class. These are the layered anionic clays with solvent-accessible interstitial galleries $[47,48$, 50-54] (Figure 4). They distinguish themselves from solids such as greigite by several properties particularly pertinent to emergence-of-life scenarios:

- The surface area available for catalytic processes exceeds that of a solid crystal by orders of magnitude.

- Water activity within the interstitial spaces is substantially decreased with respect to bulk water [26] entailing displaced equilibria for chemical transformations [39] which involve uptake or release of water molecules.

- Local dielectric constants in the interlayer spaces differ strongly from that of bulk water due to the lowered water activity and restricted mobility of individual water molecules [55].

- Interstitial spaces can accommodate a variety of counterions with a wide range of bulkiness. Layered minerals therefore can swell and shrink to extraordinary extents in response to the chemical composition of their surrounding solvent. 
Well aware of these enticing properties, the clay community has advocated a pivotal role of clays in life's emergence already since quite some time [56-60]. However, the considered minerals were mainly clays devoid of transition metals and hence redox-inactive and the relevant catalytic reactions therefore mostly revolved around surface-facilitated condensation reactions [60-62]. The mineral we single out here, i.e., fougerite, by contrast, uniquely combines the fascinating redox abilities of transition metal bearing solids such as greigite or mackinawite and the above-mentioned particularities of clay-like layered structures. Most intriguingly, fougerite couples redox and structural features in ways eerily reminiscent of bioenergetic systems as we shall detail below.

\section{insert Figure 4 close to here (width: $12 \mathrm{~cm}$ )}

\subsection{Fougerite and Green Rusts}

Fougerite is the naturally occurring form of the synthetic mineral Green Rust (GR), known to the mineralogists since almost 100 years $[56,57]$. GRs are layered double-hydroxide (LDH) minerals (sometimes also called double layered oxyhydroxides, to emphasize the coexistence of two distinct layers). In GR, the metals within the oxyhydroxide layers are $\mathrm{Fe}^{2+}$ and $\mathrm{Fe}^{3+}$ (with variable stoichiometry, see below) and the interstitial galleries contain ordered water molecules and small anions (Figure 4). We have described bio-relevant properties of GR in more detail recently [47] and will in the following focus on a few key features. Fougerite as a natural form of GRs is obviously less well-behaved than its synthetic counterparts with occasional Fe-sites being replaced by other divalent metal cations such as $\mathrm{Ni}, \mathrm{Mg}, \mathrm{Al}$, and $\mathrm{Zn}$ [54]. While the mineralogists' GR samples are usually prepared with a single type of interstitial anion (such as chloride, carbonate, sulfate, etc.), fougerite certainly contains a mixture of all kinds of anions present in the respective environments. So far, in-depth characterizations of properties and reactivities have only been obtained for the synthetic GRs. It is safe to expect that the reactional versatility of fougerite surpasses that of GRs by a wide margin due to the pronounced variability of metal ions in the oxyhydroxide layers and of counterions in the interstitial spaces.

In contrast to solid minerals which tend to grow to truly macroscopic sizes, GR only forms nanocrystals with hexagonal crystal symmetry and typical dimensions in the range of several 
nanometers to 2000 nanometers (Figure 4a). An average nanocrystal contains a few tens of Feoxyhydroxide layers. We emphasize that the smallest types of GR nanocrystals thus feature sizes comparable to those of typical bioenergetic enzymes. GRs' extraordinary physicochemical peculiarities detailed below further narrow the gap between these inorganic structures and life.

\subsubsection{Softness of Internal Structure}

While crystals are commonly associated with rigidity, this picture is strongly inappropriate when dealing with GR (or clay-like minerals in general). Clay-like assemblages substantially morph in response to the chemical composition of their solvent environment. This is due to their interstitial spaces being contiguous with the outside bulk solvent and the resulting possibility of counterions with strongly differing bulkiness being able to diffuse into these galleries [54]. In GR, the beststudied examples are those of the so-called GR1 and GR2-variants containing chloride and sulfate counterions, respectively. The height of the interlayer space of GR 1 is about $8 \AA$ which swells to $12 \AA$ during the sulfate-induced transition to GR2 while long-chain carbohydrate chains have been observed to push interlayer heights up to $40 \AA$ and above [63]. The arrangement of counterions in the interlayer space also varies considerably. Spherical or "flat" anions (e.g., chloride, carbonate, hydroxide) tend to form a single interlayer in the middle of the interstitial galleries [64]. Tetragonal anions such as sulfate (and possibly phosphate), by contrast, arrange themselves into two superimposed interlayers [65]. Individual nanocrystals can harbor mixed populations of flat and tetragonal anions resulting in undulated geometries of layer/interlayer stacks (Figure $5[54,66])$.

\section{insert Figure 5 close to here (width: $12 \mathrm{~cm}$ )}

\subsubsection{Redox Softness, Electron Transfer, and Proton-Coupled Redox Transitions}

As mentioned, iron-oxyhydroxide layers of GR are characterized by the coexistence of ferric and ferrous iron sites in the lattice. In the presence of oxygen, all iron sites are gradually converted to the ferric state resulting in the transformation of the typical GR layering into the true solids magnetite and goethite via lepidocrocite (still a layered mineral but devoid of anion interlayers). 
GRs thus are a metastable manifestation of iron oxides carving out a niche of existence in between the soluble $\mathrm{Fe}^{2+}$ oxides and the mentioned fully oxidized forms. In the absence of oxygen (or other oxidizing agents), GRs are long-term stable (that is, for months and years) in the range of $\mathrm{Fe}^{3+} / \mathrm{Fe}^{\text {tot }}$ ratios ranging from $1 / 3$ to $2 / 3$ (see Figure 4b) [67]. However, GR samples can be taken to the fully oxidized (all $\mathrm{Fe}^{3+}$ ) and fully reduced (all $\mathrm{Fe}^{2+}$ ) states for minutes to hours without losing the GR-typical layering [68]. These shifts in reduction state correspond to effective electron transfer within the plane of the Fe-oxyhydroxide layer.

Altering the $\mathrm{Fe}^{3+} / \mathrm{Fe}^{\text {tot }}$ ratio amounts to changing the net charge of the oxyhydroxide layers. To maintain their structural integrity in the face of growing charge imbalance, the GR nanocrystals can adjust the amount of compensating counter charges in the interlayer or, for the case of very high $\mathrm{Fe}^{3+} / \mathrm{Fe}^{\text {tot }}$ values, deprotonate the $\mu$-hydroxo bridges to result in $\mu$-oxo-bridged structures (Figure 5). Oxidation of the layers is therefore accompanied by release of protons into the interlayer space (which certainly sounds familiar to the bioenergeticist). For the case of inplane vectorial migration of $\mathrm{Fe}^{3+}$ sites, it is tempting to assume that the compensating counteranions in the interlayer space will tend to be dragged along and thus move in the inverse direction of effective electron flow (Figure 5). Again, the analogies to phenomena in bioenergetic transmembrane transport are intriguing.

\subsubsection{Multi-Electron Redox Catalysis}

The catalytic versatility of GR is showcased in several dedicated review articles from the mineralogical community [64]. GR's abilities to mediate challenging multi-electron redox transformations appear of particular interest to emergence of life scenarios which try to obey the thermodynamic and bioenergetic strictures laid out in Sections 1 and 2. For example, GR has been shown to catalyze the 8-electron reduction of nitrate to ammonia [37] as well as several intermediate steps thereof [66]. These reactions are intriguing since, apart from producing strongly reduced nitrogen compounds required for instance in the synthesis of amino acids, they can produce highly reactive intermediates such as nitrogen oxide [66] or potentially hydrazine [47]. 
Although a plethora of GR-assisted redox transformations have been reported by the mineralogists, the list is almost certainly far from complete and GRs are likely to feature further intriguing reaction pathways. Naturally occurring fougerite can safely be expected to show even broader reactive abilities due to the presence of transition metals other than only iron. As indicated in Section 2 and Figure 3, the top-down lead from biology to GR arises from the structural resemblance between the catalytic center of members of the diiron hydroxylase superfamily and in particular of the enzyme "soluble methane monooxygenase" and the arrangement of the Fe-oxyhydroxide layers. The diversity of diiron hydroxylases may suggest further reaction schemes to be assayed in GR samples.

\subsection{A Potential Bridge from the Inorganic World to Biology}

The above listed properties of GRs are certainly fascinating and potentially important for emergence of life scenarios. However, as we have tried to convey in Sections 1 and 6 as well as in a recent article [48], none of these properties by themselves can rationalize an emergence of life which would be in line with the $2^{\text {nd }}$ law of thermodynamics. Even the most intricate types of redox catalyses remain "catalyses", that is, they facilitate exergonic reactions rather than driving endergonic ones. What is required for credible emergence of life scenarios is the availability of disequilibria-converting processes, ideally somehow resembling the conversion of environmental redox tensions into phosphate-group transfer disequilibria such as high $\mathrm{ATP} / \mathrm{ADP}$ or $\mathrm{PP} / \mathrm{P}_{\mathrm{i}}$ ratios, as observed in real life [47]. We imagine that the synergy of GR's properties listed in Sections 6.1.1 to 6.1.3 may be able to bring forth such disequilibria-converting processes [39] and we have proposed tentative models in recent articles [47, 48].

However, we also consider that these scenarios are too speculative to be detailed in this contribution which we would like to keep as close as possible to empirical data, basic thermodynamic considerations and undeniable structural analogies. The model we have proposed nevertheless serves as proof of principle that disequilibria-converting systems based on the synergy of fougerite, mackinawite and greigite and resembling actual biology can be conceived of. Our specific model may become falsified in the future via experimental results and replaced by other scenarios but we strongly suspect that the discussed properties of the layered Fe- 
oxyhydroxide minerals will play pivotal roles also in these future scenarios.

\section{CONCLUSION}

Whether it was the presence of organic building blocks or the emergence of an ancestral metabolism based on mineral-borne inorganic metal clusters [17, 25, 27, 33, 38, 69] appears to be presently the main controversy animating the field of emergence of life research. While organic soup hypotheses have dominated the field since almost a century [70-72], the alternative current of thought is with us since quite some time, too [24] and many inorganic chemists shared David Garner's view that "It is the inorganic elements that bring organic chemistry to life" already several decades ago. Earlier emergence of life scenarios building on alkaline vent settings strongly relied on the inorganic nature of both the redox substrates and the metal catalysts of certain types of prokaryotic energy metabolism to infer a close resemblance between these metabolisms and abiotic chemical reactions occurring in the vents $[17,73,74]$.

In the past, more than half of the authors of the present contribution championed the alkaline hydrothermal vent scenario precisely because of the perceived similarity of catalytic reaction steps in the vent and in biological methano- and acetogenesis. We have since became convinced by the incontrovertible arguments from thermodynamics that abiogenesis cannot simply correspond to a speeding up of abiotic chemical reactions. Life's most fundamental nature as an entropy-lowering process requires the existence of conversion mechanisms transducing environmental disequilibria into the highly ordered factories of living cells. As we have tried to argue in this contribution, this stricture further strengthens the lead towards metalcontaining minerals as midwives for nascent life but requires the inclusion of minerals which are able to couple redox reactions and mass transfer as well as to perform proton-coupled electron transfer. 


\section{ACKNOWLEDGMENTS}

SD's and WN's work was supported by the CNRS (Défi Origines, grant SIAM). EB's contribution was partly supported by the NASA Astrobiology Institute under a cooperative agreement issued through the Science Mission directorate, no. NNH06ZDA001N (Universal Biology). MJR is supported by the National Aeronautics and Space Administration, through the NASA Astrobiology Institute under cooperative agreement issued through the Science Mission directorate; No. NNH13ZDA017C (Icy Worlds).

\section{ABBREVIATIONS AND DEFINITIONS}

$\begin{array}{ll}\text { ADP } & \text { adenosine 5'-diphosphate } \\ \text { ATP } & \text { adenosine 5'-triphosphate } \\ \mathrm{CO}_{2} & \text { carbon dioxide } \\ \text { EPR } & \text { electron paramagnetic resonance } \\ \text { EXAFS } & \text { extended X-ray absorption fine structure } \\ \text { GR } & \text { Green Rust } \\ K_{\mathrm{S}} & \text { stability constant of semireduced form of 2-electron compounds } \\ \text { LDH } & \text { layered double-hydroxide } \\ \mathrm{Mo} & \text { molybdenum } \\ \mathrm{NAD}(\mathrm{P}) \mathrm{H} & \text { nicotinamide adenine dinucleotide(phosphate), reduced } \\ {[\mathrm{NiFe}]} & \text { nickel-iron } \\ \mathrm{P}_{\mathrm{i}} & \text { orthophosphate } \\ \text { PP } & \text { pyrophosphate } \\ \text { W } & \text { tungsten } \\ \mathrm{XANES} & \text { X-ray absorption near-edge spectroscopy }\end{array}$




\section{REFERENCES}

1. Aristotle, De Generatione Animalium (On the generation of animals), 4th century BC.

2. J. R. Porter, Bacteriol. Rev. 1961, 25, 389-403.

3. C. D. Neish, A. Somogyi, M. A. Smith, Astrobiology 2010, 10, 337-347.

4. K. Altwegg, H. Balsiger, A. Bar-Nun, J. J. Berthelier, A. Bieler, P. Bochsler, C. Briois, U. Calmonte, M. R. Combi, H. Cottin, J. De Keyser, F. Dhooghe, B. Fiethe, S. A. Fuselier, S. Gasc, T. I. Gombosi, K. C. Hansen, M. Haessig, A. Jäckel, E. Kopp, A. Korth, L. Le Roy, U. Mall U, B. Marty, O. Mousis, T. Owen, H. Rème, M. Rubin, T. Sémon, C. Y. Tzou, J. Hunter Waite, P. Wurz, Sci. Adv. 2016, 27, 2.

5. S. Kwok, Orig. Life Evol. Biosph. 2015, 45, 113-121.

6. E. Schrödinger, What is life? The Physical Aspect of the Living Cell, Cambridge University Press, Cambridge, 1944.

7. G. Nicolis, Y. Prigogine, Exploring Complexity, St. Martin's Press, New York, 1989.

8. D. Kondepudi, I. Prigogine, Modern Thermodynamics; From Heat Engines to Dissipative Structures, John Wiley \& Sons, Chichester/UK, 1998.

9. E. Branscomb, M. J. Russell, Biochim. Biophys. Acta 2013, 1827, 62-78.

10. E. Branscomb, T. Biancalani, N. Goldenfeld, M. J. Russell, Physics Reports 2017, 677, 160.

11. R. G. Endres, Sci. Rep. 2017, 7, 14437.

12. B. Schoepp-Cothenet, R. van Lis, A. Atteia, F, Baymann, L. Capowiez, A.-L. Ducluzeau, S. Duval, F. ten Brink, M. J. Russell, W. Nitschke, Biochim. Biophys. Acta 2013, 1827, 79-93.

13. F. Baymann, B. Schoepp-Cothenet, S. Duval, M. Guiral, M. Brugna, C. Baffert, M. J. Russell, W. Nitschke, Front. Microbiol. 2018, 9, 13577.

14. R. F. Anderson, Biochim. Biophys. Acta 1980, 590, 277-281.

15. H. Beinert, R. H. Holm, E. Münck, Science 1997, 277, 653-659.

16. H. Beinert, J. Biol. Inorg. Chem. 2000, 5, 2-15.

17. M. J. Russell, W. Martin, Trends Biochem. Sci. 2004, 24, 358-363. 
18. W. Nitschke, M. J. Russell, J. Mol. Evol. 2009, 69, 481-496.

19. W. Nitschke, S. E. McGlynn, E. J. Milner-White, M. J. Russell, Biochim. Biophys. Acta 2013, 1827, 871-881.

20. M. J. Russell, L. M. Barge, R. Bhartia, D. Bocanegra, P. J. Bracher, E. Branscomb, R. Kidd, S.E. McGlynn, D. H. Meier, W. Nitschke, T. Shibuya, S. Vance, L. White, I. Kanik, Astrobiology 2014, 14, 308-343.

21. E. L. Shock, E. S. Boyd, Elements 2015, 11, 395-411.

22. E. J. Milner-White, M. J. Russell, Biology Direct 2008, 3, 3.

23. E. J. Milner-White, Interface focus 2019, 9, 20190057.

24. M. J. Russell, A. J. Hall, A. G. Cairns-Smith, P. S. Braterman, Nature 1988, 336, 117.

25. M. J. Russell, A. J. Hall, J. Geol. Soc. Lond. 1997, 154, 377-402.

26. M. J. Russell, Life 2018, 8, 35.

27. G. Wächtershäuser, System. Appl. Microbiol. 1988, 10, 207-210.

28. M. Yamamoto, R. Nakamura, T. Kasaya, H. Kumagai, K. Suzuki, K. Takai, Angew. Chem. Int. Ed. 2017, 56, 5725-5728.

29. L. M. White, T. Shibuya, S. D. Vance, L. E. Christensen, T. Bhartia, R. Kidd, A. Hoffmann, G. D. Stucky, I. Kanik, M. J. Russell, Astrobiology 2020, 20(3), in press.

30. M. Preiner, K. Igarashi, K. B. Muchowska, M. Yu, S. J. Varma, K. Kleinermanns, M. K. Nobu, Y. Kamagata, H. Tüysüz, J. Moran, W. F. Martin, bioRxiv 2019, 682955.

31. M. Preiner, J. C. Xavier, A. D. N. Vieira, K. Kleinermanns, J. F. Allen, W. F. Martin, Interface focus 2019, 9, 20190072.

32. A. Yamaguchi, M. Yamamoto, K. Takai, T. Ishii, K. Hashimoto, R. Nakamura, Electrochim. Acta. 2014, 141, 311-318.

33. C. Huber, G. Wächtershäuser, Science 1997, 276, 245-247.

34. N. Kitadai, R. Nakamura, M. Yamamoto, K. Takai, Y. Li, A. Yamaguchi, A. Gilbert, Y. Ueno, N. Yoshida, Y. Oono, Sci. Adv. 2018, 4, eaao7265.

35. A. Roldan, N. Hollingsworth, A. Roffrey, H. U. Islam, J. Goodall, C. R. A. Catlow, J. A. Darr, W. Bras, G. Sankar, K. B. Holt, G. Hogarth, N. H. de Leeuw, Chem. Commun. 2015, $51,7501-7504$. 
36. H. C. Hansen, O. K. Borggaard, J. Sørensen, Geochim. Cosmochim. Acta 1994, 58, 25992608.

37. H. C. B. Hansen, Appl. Clay Science 2001, 18, 81-91.

38. C. Huber, G. Wächtershäuser, Tetrahedron Lett. 2003, 4, 1695-1697.

39. L. M. Barge, E. Flores, M. M. Baum, D. G. VanderVelde, M. J. Russell, Proc. Natl Acad. Sci. 2019, 116, 4828-4833.

40. Q. Wang, L. M. Barge, O. Steinbock, Chem. Eur. J. 2019, 25, 4732-4739.

41. R. Hedderich, L. Forzi, J. Mol. Microbiol. Biotechnol. 2005, 10, 92-104.

42. D. G. Nicholls, S. J. Ferguson, Bioenergetics 4, 4th edition, Academic Press, London, UK, 2013.

43. W. Buckel, R. K. Thauer, Biochim. Biophys. Acta 2013, 1827, 94-113.

44. W. Nitschke, M. J. Russell, Bioessays 2012, 34, 106-109.

45. J. L. Yuly, C. E. Lubner, P. Zhang, D. N. Beratan, J. W. Peters, Chem. Commun. 2019, 55, 11823-11832; doi: 10.1039/c9cc05611d.

46. S. Duval, J. M. Santini, D. Lemaire, F. Chaspoul, M. J. Russell, S. Grimaldi, W. Nitschke, B. Schoepp-Cothenet, Biochim. Biophys. Acta 2016, 1857, 1353-1362.

47. S. Duval, F. Baymann, B. Schoepp-Cothenet, F. Trolard, G. Bourrié, O. Grauby, E. Branscomb, M. J. Russell, W. Nitschke, Interface focus 2019, 9, 20190063. doi:10.1098/rsfs.2019.0063.

48. S. Duval, E. Branscomb, F. Trolard, G. Bourrié, O. Grauby, V. Heresanu, B. SchoeppCothenet, M. J. Russell, W. Nitschke, Applied Clay Sci. 2020, 195, 105737.

49. L. M. White, R. Bhartia, G. D. Stucky, I. Kanik, M. J. Russell, Earth Planet. Sci. Lett. 2015, 430, 105-114.

50. G. Arrhenius, Interaction of Hydrous Minerals with Bioorganic Precursor Molecules. In NASA Space Life Sciences Symposium, Washington DC, June 21-26, 1987, pp. 260-261.

51. G. O. Arrhenius, Helv. Chim. Acta 2003, 86, 1569-1586.

52. F. Trolard, G. Bourrié, M. Abdelmoula, P. Refait, F. Feder, Clays and Clay Minerals 2007, $55,323-334$. 
53. J. M. R. Génin, R. Aïssa, A. Géhin, M. Abdelmoula, O. Benali, V. Ernstsen, G. OnaNguema, C. Upadhyay, C. Ruby, Solid State Sciences 2005, 7, 545-572.

54. M. I. Agnel, S. Grangeon, F. Fauth, E. Elkaïm, F. Claret, M. Roulet, F. Warmont, C. Tournassat, Environm. Sci. Technol. 2019, in press.

55. E. Branscomb, M. J. Russell, Interface Focus 2019, 9, 20190061. doi: 10.1098/rsfs.2019.0061

56. J. D. Bernal, D. R. Dasgupta, A. L. Mackay, Nature 1957, 180, 645-647.

57. J. D. Bernal, D. R. Dasgupta, A. L. Mackay, Clay Minerals Bulletin 1959, 4, 15-30.

58. A. G. Cairns-Smith, Genetic Takeover and the Mineral Origins of Life, Cambridge University Press, Cambridge, UK, 1982.

59. D. H. Solomon, Clays and Clay Minerals 1968, 16, 31-39.

60. M. Rao, D. G. Odom, J. Oro, J. Mol. Evol. 1980, 15, 317-331.

61. D. G. Odom, M. Rao, J. G. Lawless, J. Oro, J. Mol. Evol. 1979, 12, 365-367.

62. N. Kitadai, K. Nishiuchi, Astrobiology 2019, 19, 1363-1376. doi: 10.1089/ast.2018.1967

63. K. B. Ayala-Luis, C. B. Koch, H. C. B. Hansen, Appl. Clay Sci. 2010, 48, 334-341.

64. M. Usman, J. M. Byrne, A. Chaudhary, S. Orsetti, K. Hanna, C. Ruby, A. Kappler, S. B. Haderlein, Chem. Rev. 2018, 118, 3251-3304.

65. L. Simon, M. François, P. Refait, G. Renaudin, M. Lelaurain, J.-M. R. Génin, Solid State Sci. 2003, 5, 327-334.

66. D. Guerbois, G. Ona-Nguema, G. Morin, M. Abdelmoula, A. M. Laverman, J. M. Mouchel, K. Barthelemy, F. Maillot, J. Brest, Environ. Sci. Technol. 2014, 48, 4505-4514.

67. J.-M. R. Génin, P. Refait, G. Bourrié, M. Abdelmoula, F. Trolard, Appl. Geochem. 2001, 16, 559-570.

68. J.-M. R. Génin, C. Ruby, C. Upadhyay, Solid State Sci. 2006, 8,1330-1343.

69. E. Camprubi, S. F. Jordan, R. Vasiliadou, N. Lane, IUBMB Life 2017, 69, 373-381.

70. J. B. S. Haldane, Rationalist Annual 1929, 3, 3-10.

71. A. I. Oparin, Origin of Life, McMillan, New York, 1938.

72. S. L. Miller, H. C. Urey, Science 1959, 130, 245-251.

73. W. Martin, M. J. Russell, Philos. Trans. Roy. Soc. London B 2007, 362,1887-925. 
74. N. Lane, The Vital Question. Energy, Evolution and the Origins of Complex Life, Norton \& Company, New York, USA, 2015. 
Table 1

\begin{tabular}{|c|c|c|c|}
\hline Reaction & Mineral/Cation & Conditions & Refs \\
\hline $\begin{array}{l}\mathrm{H}_{2} \rightarrow 2 \mathrm{H}^{\cdot} \rightarrow 2 \mathrm{H}^{+}+2 \mathrm{e}^{-} \\
\mathrm{H}_{2} \mathrm{~S} \rightarrow 2 \mathrm{H}^{+}+2 \mathrm{e}^{-}+\mathrm{S}^{0} \quad \text { ELECTRONS }\end{array}$ & $\begin{array}{l}\text { Unspecified Fe-S } \\
\text { conductors }\end{array}$ & $\begin{array}{l}\text { Induced/natural chimneys } \\
309^{\circ} \text { to } 4^{\circ} \mathrm{C}, \mathrm{pH} 4.8 \text { to } 7\end{array}$ & {$[28]$} \\
\hline $\mathrm{H}_{2}+\mathrm{CO}_{2} \rightarrow \mathrm{HCOOH}$ & $\begin{array}{l}\text { Fe-Ni sulfides, } \\
\text { Awaruite } \mathrm{Ni}_{3} \mathrm{Fe} \\
\text { Greigite } \mathrm{Fe}_{3} \mathrm{~S}_{4} \\
\text { Magnetite } \mathrm{Fe}_{3} \mathrm{O}_{4}\end{array}$ & $\begin{array}{l}120^{\circ} \mathrm{C}, \mathrm{pH} 5 \text { to } 11 \\
100^{\circ} \mathrm{C}, \mathrm{pH} 5 \text { to } 11\end{array}$ & $\begin{array}{l}{[29]} \\
{[30} \\
31]\end{array}$ \\
\hline $\mathrm{CO}_{2}+2 \mathrm{H}^{+}+2 \mathrm{e}^{-} \rightarrow \mathrm{CO}+\mathrm{H}_{2} \mathrm{O}$ & Violarite $\mathrm{FeNi}_{2} \mathrm{~S}_{4}$ & $\begin{array}{l}25^{\circ} \mathrm{C}, \mathrm{pH} \sim 5.5 \text { to } 9.5 \\
1.1 \mathrm{~V}\end{array}$ & {$[32]$} \\
\hline $\begin{array}{l}\mathrm{CH}_{3} \mathrm{~S}^{-}+\mathrm{CO}+\mathrm{H}_{2} \mathrm{O} \rightarrow \mathrm{CH}_{3} \mathrm{COO}^{-}+\mathrm{H}_{2} \mathrm{~S} \\
\text { ACETATE } \\
\text { via } \mathrm{CH}_{3} \mathrm{SH}+\mathrm{CO} \rightarrow \mathrm{CH}_{3} \mathrm{COSH}\end{array}$ & $\mathrm{FeS}, \mathrm{NiS}\left(\mathrm{NiSO}_{4}\right)$ & $100^{\circ} \mathrm{C}, \mathrm{pH} 6$ to 9 & {$[33]$} \\
\hline $\mathrm{CO}_{2}+2 \mathrm{H}_{2} \rightarrow \mathrm{CH}_{3} \mathrm{OH}+\mathrm{H}_{2} \mathrm{O} . \quad$ METHANOL & $\begin{array}{l}\text { Awaruite } \mathrm{Ni}_{3} \mathrm{Fe} \\
\text { Greigite } \mathrm{Fe}_{3} \mathrm{~S}_{4} \\
\text { Magnetite } \mathrm{Fe}_{3} \mathrm{O}_{4}\end{array}$ & $100^{\circ} \mathrm{C}, \mathrm{pH} 5$ to 11 & {$[30]$} \\
\hline $\begin{array}{r}2 \mathrm{CO}_{2}+8 \mathrm{H}^{+}+8 \mathrm{e}^{-} \rightarrow \mathrm{CH}_{3} \mathrm{COOH}+2 \mathrm{H}_{2} \mathrm{O} \\
\text { ACETIC ACID }\end{array}$ & Greigite $\mathrm{Fe}_{3} \mathrm{~S}_{4}$ & $\begin{array}{l}25^{\circ} \mathrm{C}, \mathrm{pH} 6.5+ \\
0.2 \mathrm{~V} \text { and } 0.8 \mathrm{~V}\end{array}$ & {$[34]$} \\
\hline $\begin{array}{r}3 \mathrm{CO}_{2}+2 \mathrm{H}_{2} \rightarrow \mathrm{CH}_{3} \mathrm{COCOOH} \\
\text { PYRUVIC ACID }\end{array}$ & $\begin{array}{l}\text { Magnetite } \mathrm{Fe}_{3} \mathrm{O}_{4} \\
\text { Awaruite } \mathrm{Ni}_{3} \mathrm{Fe}\end{array}$ & $100^{\circ} \mathrm{C}, \mathrm{pH} 7$ to 10 & {$[30]$} \\
\hline $\begin{array}{r}3 \mathrm{CO}_{2}+10 \mathrm{H}^{+}+10 \mathrm{e}^{-} \rightarrow \mathrm{CH}_{3} \mathrm{COCOOH}+3 \mathrm{H}_{2} \mathrm{O} \\
\text { PYRUVIC ACID }\end{array}$ & Greigite $\mathrm{Fe}_{3} \mathrm{~S}_{4}$ & $\begin{array}{l}25^{\circ} \mathrm{C}, \mathrm{pH} 6.5+ \\
0.2 \mathrm{~V} \leftrightarrow \square 0.8 \mathrm{~V}\end{array}$ & {$[35]$} \\
\hline $\mathrm{NO}_{2}^{-}+\mathrm{Fe}^{2+}+2 \mathrm{H}^{+} \rightarrow \mathrm{NO}+\mathrm{Fe}^{3+}+\mathrm{H}_{2} \mathrm{O}$ & Fougerite & $25^{\circ} \mathrm{C}, \mathrm{pH} 6.6$ & {$[36]$} \\
\hline $\mathrm{NO}_{3}{ }^{-}+4 \mathrm{H}_{2} \rightarrow \mathrm{NH}_{3}+2 \mathrm{H}_{2} \mathrm{O}+\mathrm{OH}^{-}$ & Fougerite & $25^{\circ} \mathrm{C}, \mathrm{pH} 8$ & {$[37]$} \\
\hline $\begin{array}{l}\text { R.CO.COO }{ }^{-}+\mathrm{NH}_{4} \mathrm{Cl}+\mathrm{H}_{2} \rightarrow \text { R.CH}\left(\mathrm{NH}_{2}\right) \mathrm{COO}^{-} \\
+\mathrm{H}_{2} \mathrm{O}+\mathrm{HCl} \\
\quad \text { AMINO ACIDS: ALA, GLU, PHE, TYR }\end{array}$ & $\begin{array}{l}\text { FeS, } \mathrm{Fe}(\mathrm{OH})_{2} \\
\text { (Mackinawite, } \\
\text { White Rust?) }\end{array}$ & $50^{\circ}$ to $100^{\circ} \mathrm{C}, \mathrm{pH} 8.3$ to 10.5 & {$[38]$} \\
\hline $\begin{array}{l}\mathrm{CH}_{3} \mathrm{CO} \cdot \mathrm{COO}^{-}+\mathrm{NH}_{3}+\mathrm{H}_{2} \rightarrow \\
\mathrm{CH}_{3} \mathrm{CH}\left(\mathrm{NH}_{2}\right) \mathrm{COO}^{-}+\mathrm{H}_{2} \mathrm{O}\end{array}$ & Fougerite & $50^{\circ} \mathrm{C}, \mathrm{pH} 9$ to 11 & [39] \\
\hline 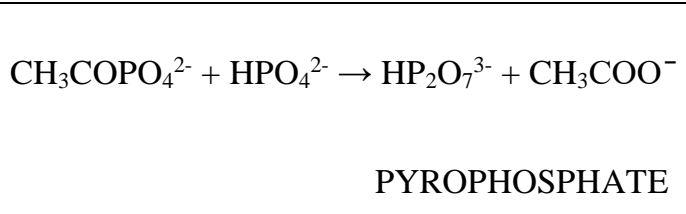 & $\begin{array}{l}\text { Goethite, } \alpha-\mathrm{FeOOH} \\
\text { Vivianite, } \\
\text { Fougerite }\end{array}$ & $22^{\circ} \mathrm{C}, \mathrm{pH} 2.2$ to 7.3 & {$[40]$} \\
\hline
\end{tabular}

Legend: Reactions catalyzed by 3D sulfides and oxides, and a 2D oxyhydroxide (fougerite) and sulfide (mackinawite) expected to have occurred at a Hadean alkaline submarine vent as demonstrated in the lab or field. Reactions are depicted either at equilibrium or driven electrochemically [26]. All potentials are with respect to the normal hydrogen electrode. 


\section{Figure Legends}

Figure 1. Schematic illustration of the main message emerging from the synthesis of far-fromequilibrium thermodynamics and bioenergetics in extant life. In the absence of environmental thermodynamic disequilibria, a random distribution of the elements involved in living systems can only be expected to become even more random (arrow to the left; note that the sample of elements is not exhaustive but reflects what appears most important to us for proper functioning of living cells). The situation is completely different if environmental disequilibria are available which can drive the formation of dissipative structures (arrow to the right), the raison d'être of which is, as is in their name, to more rapidly dissipate the environmental disequilibria. In extant biology, the driving disequilibrium is electrochemical (symbolized by the battery) and we consider that it also was when life emerged. In extant life, electrochemical free energy is transduced into far-from-equilibrium ratios of $\mathrm{ATP}$ to $\mathrm{ADP}$ or pyrophosphate $\left(\mathrm{PP}_{\mathrm{i}}\right)$ to orthophosphate $\left(\mathrm{P}_{\mathrm{i}}\right)$ (schematically depicted below the icon of a prokaryotic cell) which then drive all subsequent order-generating metabolic processes. It seems most parsimonious to us to assume the operation of a similar conversion process in nascent life.

Figure 2. The overwhelming majority of catalytic reactions involved in bioenergetic mechanisms of extant life is carried out by metal clusters in metalloenzymes. The figure intends to illustrate the diversity of involved metals and of the structural assembly of mixed-metal clusters present in metalloproteins (in a non-exhaustive way) and to emphasize that it is the metal part of metalloproteins that plays the crucial catalytic role rather than the protein part. Depicted centers are from the following 3D-structures: (A-D: tetrapyrrol-ligated, E-F: pterin-ligated, G-O: ligated by specific amino acids) (A) Chlorophyll from PS I of Pisum sativum with Mg central ion (4Y28); (B) Heme from fumarate reductase of Wolinella succinogenes (2BS2); (C) Cobalamin (Vit. $\mathrm{B}_{12}$ ) from the enzyme OxsB of Bacillus megaterium with cobalt in the active site (5UL3); (D) Factor F430 from methyl-CoM reductase of Methanothermobacter marburgensis containing nickel (3POT); (E) Molybdopterin cofactor of arsenite oxidase from Alcaligenes faecalis (1G8J); (F) Tungstopterin in formylmethanofuran dehydrogenase of Methanothermobacter wolfeii 
(5T5I); G. Non-cubane [4Fe-4S] cluster of heterodisulfide reductase/[Ni-Fe]-hydrogenase complex from Methanothermococcus thermolithotrophicus (5ODC); (H) Cubane [4Fe-4S] cluster from fumarate reductase of Wolinella succinogenes (2BS2); (I) [3Fe-4S] cluster from fumarate reductase of Wolinella succinogenes (2BS2); (J) Rieske [2Fe-2S] cluster in the Rieske/cytb complex of Rhodobacter sphaeroides (2NUK); (K) [Ni-Fe-S] cluster from anaerobic CODH of Carboxydothermus hydrogenoformans (3B51); (L) [Ni-Fe] cluster in the hydrogenase of Hydrogenophilus thermoluteolus (5XFA); (M) [Fe-Fe] cluster in the hydrogenase of Clostridium pasteurianum (3C8Y); (N) Copper-cluster of nitrous oxide reductase from Pseudomonas stutzeri (6RKZ); (O) Manganese-cluster in PS II from Thermosynechococcus vulcanus (3WU2). The coordinating atoms are drawn proportionally smaller and transparent.

Figure 3. Structural resemblance between the catalytic metal clusters present in three key enzymes (bottom row) involved in substrate conversions with strong relevance to emergence of life scenarios and the minerals mackinawite, greigite, and fougerite (top row).

Figure 4. Overview of basic structural features of Green Rusts. The shape and typical dimensions of the hexagonal nanocrystals of GR are depicted in (a). (b) and (c) show top and side views, respectively, of the layered structure arising from an alternating series of Feoxyhydroxide strata and charge-compensating, anion-containing interstitial galleries.

Figure 5. Schematic representation of two individual oxyhydroxide layers and their interstitial space of a Green Rust nanocrystal harboring mixed-type interstitial anions (that is, spherical ones resulting in GR1 with an interstitial height of about $8 \AA$ and tetragonal ones yielding GR2 with heights of about $12 \AA$ ). Movement of charge in the Fe-oxyhydroxide layer will be accompanied by modifications in the $\mathrm{p} K$ values of the $\mu$-bridging $\mathrm{OH}$ groups in the way that more oxidized $\left(\mathrm{Fe}^{3+}\right)$ sites are likely to induce deprotonation of their surrounding hydroxy groups and release of $\mathrm{H}^{+}$into the interstitial spaces. Movements of $\mathrm{Fe}^{3+}$ sites (corresponding to electron transfer in the opposite direction) within the layers are also expected to drag charge-compensating ions with them resulting in correlated movements of the interstitial anions. 


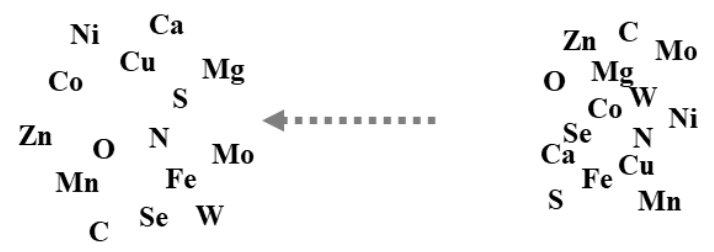

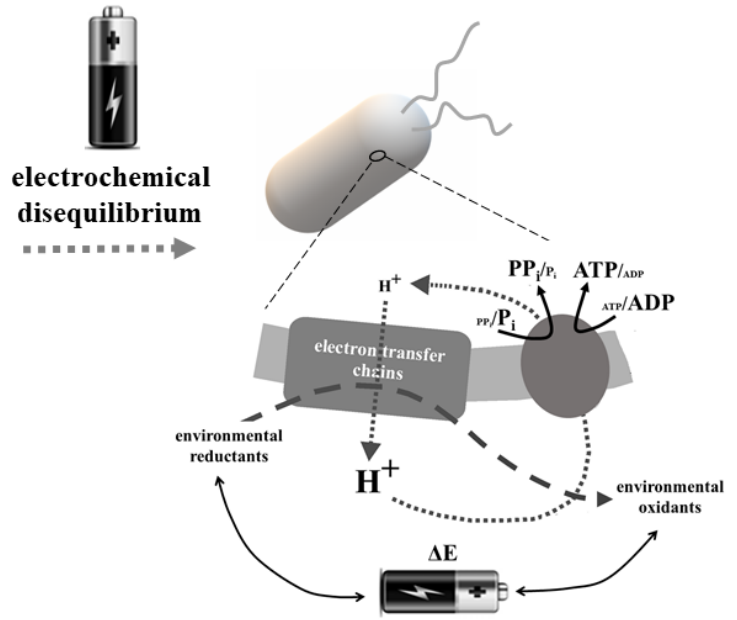

Figure 1 

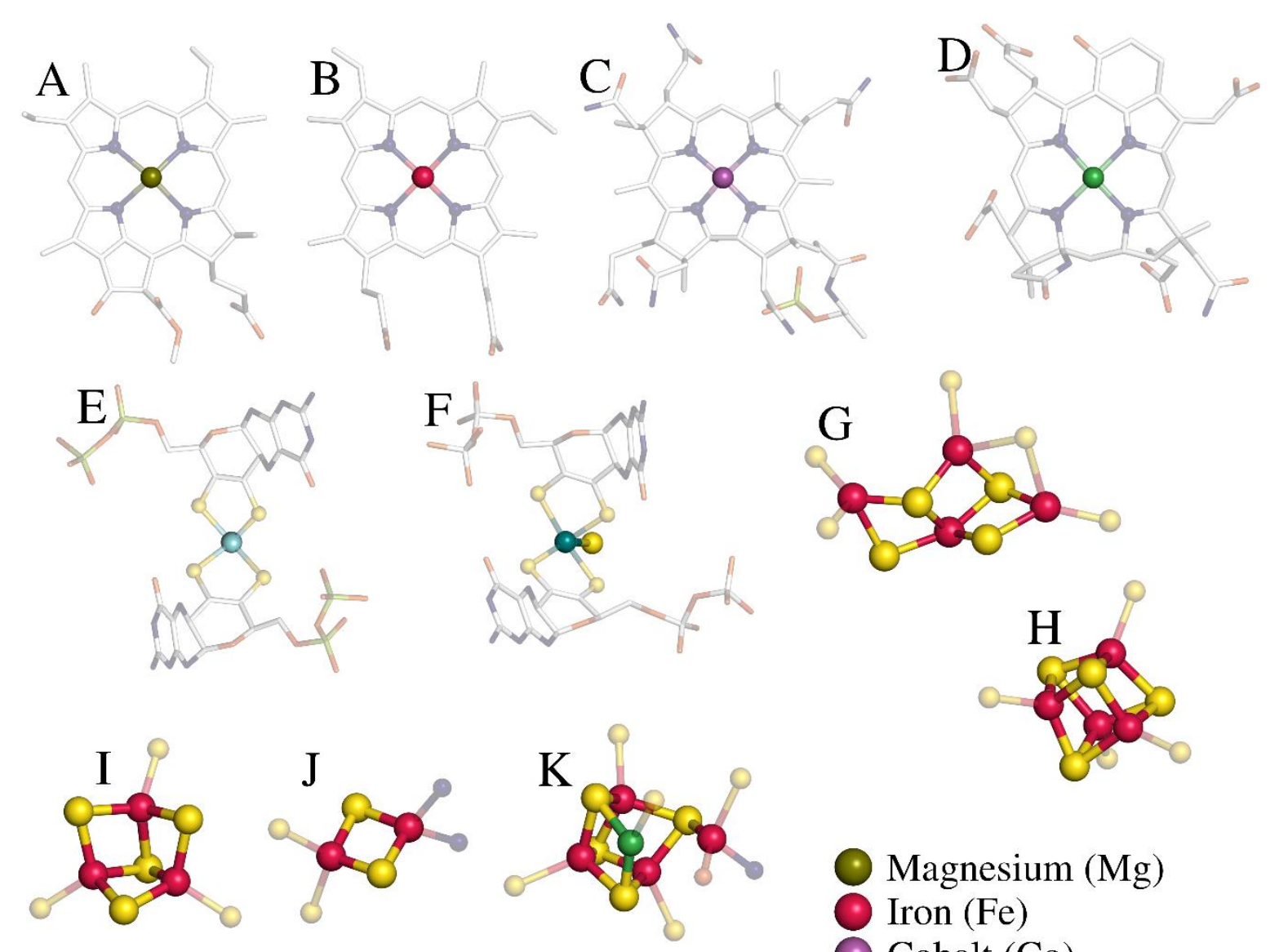
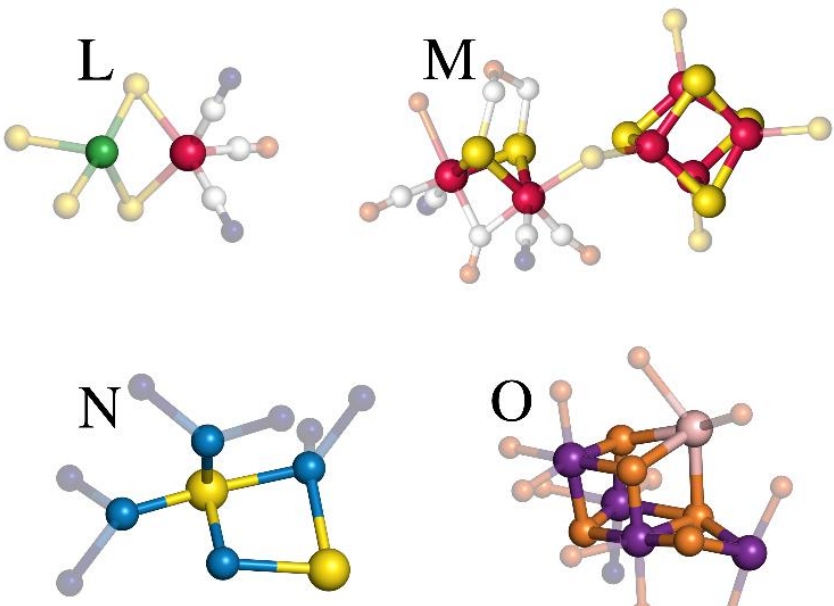

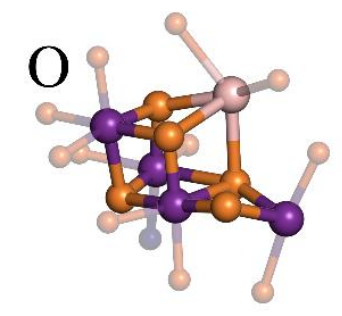

- Magnesium (Mg)

Iron (Fe)

- Cobalt (Co)

- Nickel (Ni)

Molybdenum (Mo)

- Tungsten (W)

Sulphur (S)

Copper $(\mathrm{Cu})$

- Manganese (Mn)

Calcium (Ca)

Phosphate (P)

- Carbon $(\mathrm{C})$

- Nitrogen $(\mathrm{N})$

- Oxygen (O)

Figure 2 


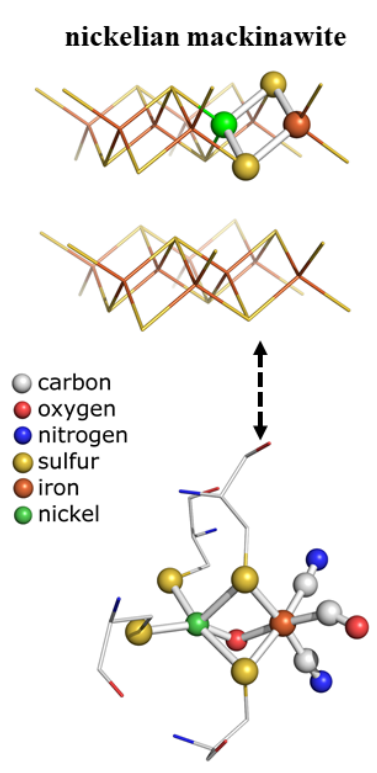

[NiFe]-hydrogenase

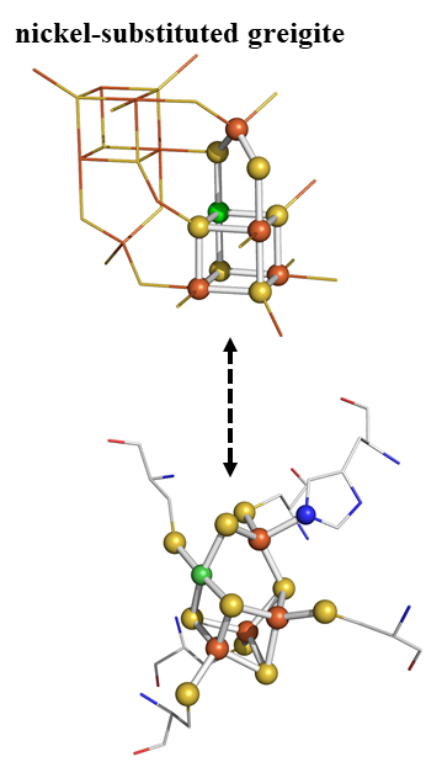

CO-dehydrogenase (C-cluster)
Green Rust (fougerite)

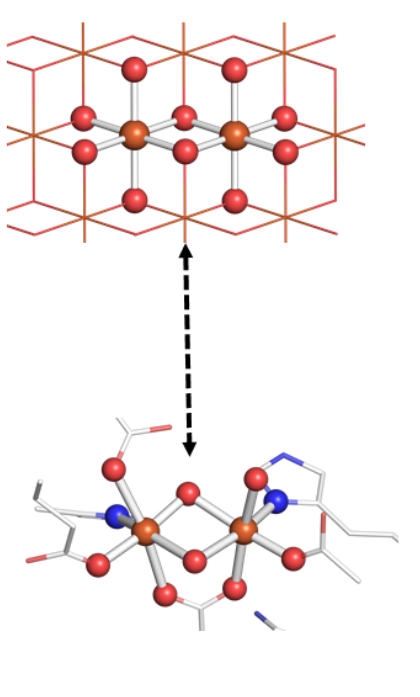

soluble methane monooxygenase

Figure 3 
(a)

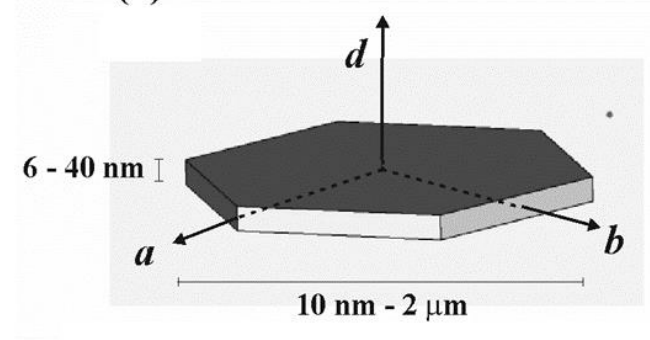

(b)

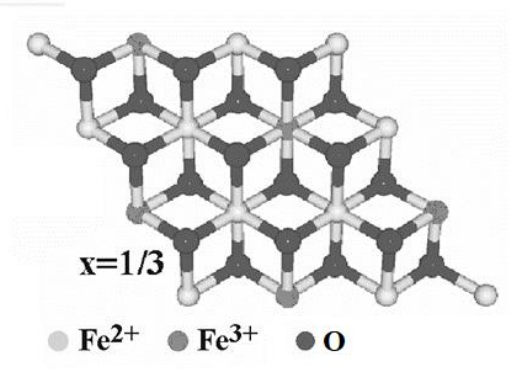

(c)

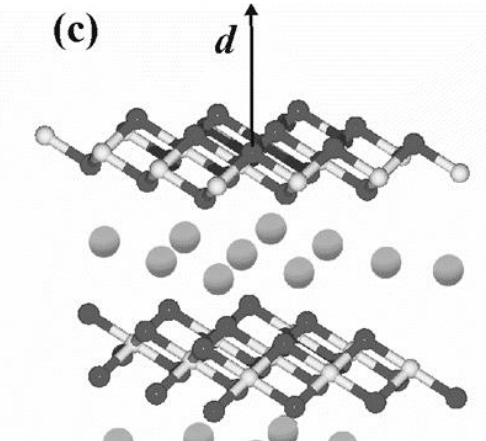

○

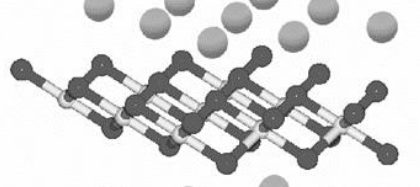

- 0.0

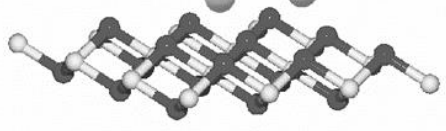

Figure 4 


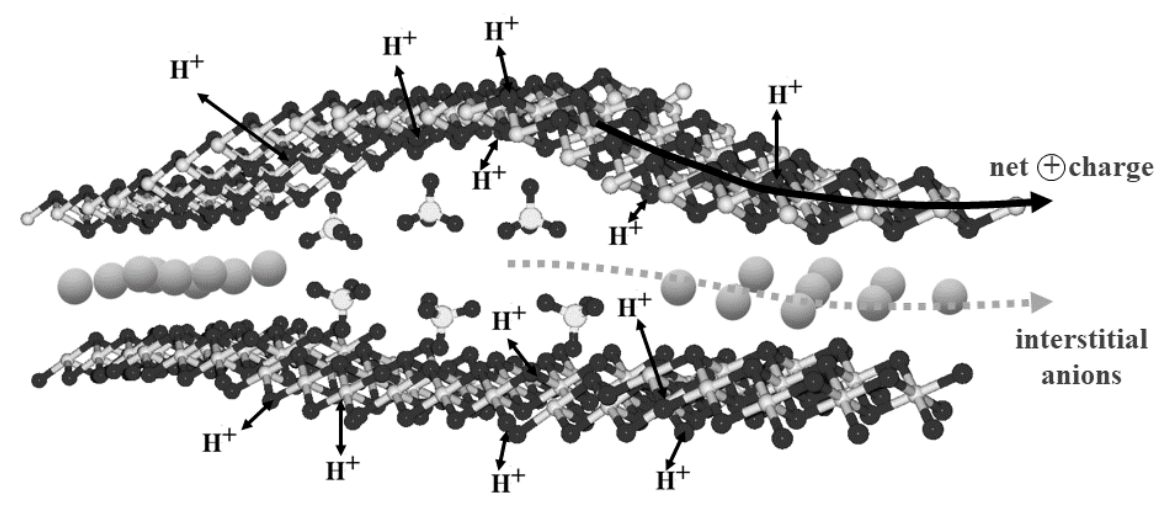

Figure 5 